\title{
Strategy Research on Finance Image of Small and Medium Enterprises in China
}

\author{
Aili $\mathrm{Wu}$ \\ Nanjing University of Finance and Economics \\ Nanjing, China
}

\begin{abstract}
Corporate finance image is a reflection of overall strength of enterprise in the market. This paper analyzes the factors of restricting the good finance image, and establishes the strategies of developing finance image from the perspective of SWOT. Its aim is to improve Small-medium Enterprise financial image.
\end{abstract}

Keywords-Small and Medium Enterprise (SME); finance image; SWOT method; strategy research

\section{INTRODUCTION}

With the deepening of market economy, corporate finance has become the topic of business and academic community. Competition in the marketplace is no longer product quality or price, but competition in comprehensive strength. Corporate finance image in the market is a reflection of overall strength, i.e. the financial position and operating results. Therefore, it is important for enterprises to enhance their finance image, so as to achieve the final victory in the fierce market competition.

Corporate finance image is simply defined as the reflection of financial position and operating results in the market. In accordance with the main elements of the image, it can be divided into image of finance entity, financial management system and financial overall strength. The characteristics of finance image are objectivity and relevance. And the significance of developing the financial image of Small and Medium Enterprises (SMEs) is as follows.

\section{A. Good Corporate Finance Image Is Helpful for Enterprises to Financing}

Funds is enterprise' blood, which is related to the enterprise's survival and development. Market economy provides enterprises with a variety of funding sources and methods. But for a specific enterprise, whether can choose suitable channels and means, the main conditions are corporate finance image, which plays very important role. The market mechanisms make funds flow to those enterprises of operating well-managed and good financial image.

\section{B. Good Corporate Finance Image Benefits Its Investment Activities}

With good finance image, enterprises are more likely to seek partners to invest to make their own investment plans

Sponsor: A Project Funded by the Priority Academic Program Development of Jiangsu Higher Education Institutions (PAPD). are successfully implemented. Any local government will welcome those enterprises which have good corporate finance image to invest locally. These local governments will provide more convenience, better conditions and benefits to those enterprises. Good corporate image is beneficial for product sales, which will help companies "brand" form and continuously improve. So it can be said that good finance image is a valuable intangible assets of enterprises.

\section{SWOT ANALYSIS OF DEVELOPMENT OF SMES FINANCE IMAGE}

SWOT is an abbreviation of four English words, representing the Strength, Weakness, Opportunity, and Threat. SWOT method provides a system analysis of various factors intertwined. This analysis aims to identify strengths and weaknesses of the existing businesses. It is not only able to identify key elements of internal resources and external environment, but also to carry out structural analysis. It is a way to analyze and research unit real circumstances more objectively and accurately.

The level of corporate governance is the most important factor of constraining enterprises' survival and development. Only in accordance with business goals, and applying scientific management methods, can enterprises maintain good corporate finance image. The key aspect of forming corporate finance image is quality of an enterprise's financial position and operating results. Thus, good finance image is the important foundation of shaping the successful image of SMEs.

\section{A. Advantages of Improving Finance Image}

\section{1) Lower costs of production and higher efficiency.}

SMEs have small-scale production, and have small industrial investment in fixed assets. They do not require lots of labor and material resources. The barriers of industrial entry and exit are very small. And the complexity of operations is simpler than large enterprises, which have simple internal organization structure and fewer employees.

2) Flexible operating model.

SMEs have flexibility and the ability to rapidly changing products. SMEs have creative and aggressive sprit, so they have great potential development. 


\section{B. Disadvantages of Improving Finance Image}

1) SMEs lack of funds, indirect financing being the main external financing

In the process of increasingly market-oriented economy, external financing becomes the enterprises' main access to finance. External financing can be classified into direct financing and indirect financing. Direct financing means enterprises get funds through capital markets (including the stock market and bond market). Indirect financing means that enterprises get funds through banks and other financial institutions. SMEs' financing channels are always limited due to the smaller scale and less investors. Limited to the ability of credit conditions and capital operation, SMEs usually do not have the conditions for direct financing, but only for indirect financing.

2) Weak financial management and low quality of accountants

Due to smaller operating scale, SMEs have relatively simple internal structure. So, the level of financial management depends largely on the owner's knowledge and ability. The accountants' quality is low. Even some small and medium enterprises do not have accounting department. They commission external accounting agency to bookkeeping.

\section{Opportunity of Improving Finance Image}

\section{1) Obtaining support of national policy.}

October 23, 2009, China initiated the GEM, which provides a new main access to finance for SMEs. This will be beneficial for SMEs to rapidly grow.

2) Most small and medium enterprises are high-tech ones. These SMEs have great potential development and its finance image has much space for development.

\section{Competitive Market}

1) Suddenly attack of competitors, changes of industry policy, unexpected events, all make some small and medium enterprises withdrawal funds, avoid bank debt, evade tax and other malicious activities. In a certain extent, these affect overall finance image of SMEs .

2) Credit policy of Financial institutions are too strict for SMEs.

Since SMEs' smaller scale, limited value of collateral, and rigorous guarantee terms, so banks generally hold discriminatory attitudes to SMEs when banks give them loans. Therefore, there are great difficulties for SMEs to finance.

\section{STRATEGY BASED ON SWOT ANALYSIS}

In order to improve the image of corporate finance, the strategy choice is the SWOT Strategy Matrix which is formed by internal condition (S\&W) and the external environment (O\&T). They are SO strategy, ST strategy, WO strategy, WT strategy. Countermeasures points are as follows.

\section{A. SO Strategy}

1) Enhance their competitiveness and strip slow moving items promptly.

When companies find that sales volume continued to decline, they should immediately analyze the causes, and research whether to change marketing strategy or even the need for business transformation. Slow-moving, products should be stripped in time to avoid inventory backlog and affect cash flow.

2) Using policy support and seeking development actively.

Mostly small and medium enterprises are high-tech ones. They had better take advantage of the SME Promotion Law promulgated by the state and the Growth Enterprise Market (GEM), so as to increase input in science and technology development funds. To enhance the overall strength of SMEs, they must make full use of the advantages of its flexibility and strong technical innovation to improve the technology content. Only in this way, can SME's financial image be enhanced.

\section{B. ST Strategy}

1) Centralizing Allocation of Resources and Strengthening Capacity of Development.

Since SMEs generally have small scale, they should concentrate limited resources on a strength point. At this point, enterprises can get the advantage to meet customers' needs than their competitors. They should adopt the professional market strategy for specific customer. So compared to large enterprises, they naturally have more competitiveness. Especially in the more fierce competitive market, according to the principles of focus, there will be more significant for small and medium enterprises to research competitive strategy.

\section{2) Improving Credit Policy and Enhancing the Credit} Rank.

Since bank is responsible for the safety and effectiveness of loans, so the conditions of loan have strict requirements. Only those enterprises can obtain bank loans that have financial strength and good finance image. Both companies issued stocks and bonds or bank loans, corporate credit is a very important condition, which depends not only on the financial status and operating results, but also on the history of corporate interest payments. The credit rank should be at A or above at least, because the image of corporate finance credit rank is an important manifestation. Therefore, the accumulation of capital for SMEs should be strengthened to improve the ratio of own funds, improve the financial management system, provide comprehensive, accurate financial information to the relevant sectors of society, and establish the good image of keeping promises, so as to win the trust of the financial sector with good honest behavior.

\section{WO Strategy}

1) Strengthening CI design and establishing financial culture.

The formation of corporate finance image results 
from the enterprise leaders' idea and level of financial culture. If business management has strong idea of financial management, high quality of financial management and high level of financial management, enterprises can establish a sound corporate financial management system, so create a good culture of corporate finance. Sound financial culture atmosphere will form a strong financial image.

2) Optimizing financial structure, and expanding financing channels.

Financial structure includes the financing structure and investment structure. On one hand, SMEs should use the capital structure which has the minimum of weighted average capital cost and the largest enterprise value. On the other hand, SMEs should optimize the investment structure to obtain the maximum expected investment return. In October 2009, China has initiated the GEMs which broaden financing channels for SMEs and provide powerful driving force for SME development.

\section{WT Strategy}

\section{1) Perfect the internal financial management system}

In order to establish a sound finance image, SMEs must establish a set of internal financial management system and must be strictly implemented. Otherwise, chaos of financial management will lead to earning reduce, which makes the company's finance image severely tarnished.

\section{2) Improving financial strength.}

The company's financial strength is a comprehensive index. If the financial strength is strong, which means the company has a strong solvency, profitability and assets management capability. These factors are important to decide good corporate finance image. They are: (1) Increase solvency. Use financial indexes to assess solvency to reduce the backlog of inventory and speed up the recovery of accounts receivable. (2) Enhance profitability. Expand sales, save costs and increase return on equity.

\section{CONCLUSION}

Development of SMEs finance image is a systematic engineering, which requires SMEs to improve their strength. At the same time it needs the support of national multilevel capital markets and favorable external environment. Only coordinate the interests of relevant parties, the trouble of finance image of SMEs can be solved effectively. Therefore, we should set effective development strategies to protect enhancement of SMEs finance image and promote healthy development of SMEs from the perspective of strategic management.

\section{REFERENCES}

[1] Wang Hong. Discussion on channels of establishing corporate finance image. Operating Manager, 2010,(11)

[2] Lu Taiping. Discussion on Corporate Finance Image. Technology Economy, 2004,(1)

[3] Zhang Xianji. Establish Good Corporate Finance Image. Economy System Reform, 2012,(5) 